\title{
YAHYA KEMAL'IN DUYGU VE DÜŞÜNCE DÜNYASINA ANNESININ TESIRLERI
}

Yahya Kemal's Mother's Influence on His World of Feeling and Thought

\section{DILEK ÇETINDAŞ*}

\section{ÖZ}

Türk edebiyatının en önemli isimlerinden olan Yahya Kemal'in hayata dair duygu ve düşüncelerinin oluşmasında annesi Nakiye Hanım'ın etkisi büyüktür. Şair henüz on üç yaşında iken kaybettiği annesi ile geçirdiği kısa ama mutlu günlerinin anılarını yıllar sonra yazdı̆ şiirlerinde işlemiştir. Bu makalede de EzânMuhammedî, Hayal Şehir, Ufuklar ve Nazar şiirler göz önüne alınarak, şairin din, tarih, ölüm v folklor konusundaki görüşlerinde annesinin tesirleri incelenmiştir.

Anahtar Sözcükler: Yahya Kemal, Anne, Biyografi, Şiir
ABSTRACT

Nakiye Hanım's influence is great on Yahya Kemal's thoughts and feelings about life, who is one of the most important figures in Turkish literature. The poet depicted in his poems the memories of his short but happy old days with his mother, which he wrote later in his life. In this article the poet's mother's influence on his views about religion, history, death and folklore were examined in the light of the poems of Ezân-1 Muhammedî, Hayal Şehir, Ufuklar and Nazar. Poem

Aristo'dan bugüne uzanan çizgide, edebiyat çoğu zaman bir iç dökme aracı olarak görülmüş ve en önemli ilkesinin samimiyet olduğuna inanılmıştır. Sanatçıların ruh çıplaklıkları olarak değerlendirilen mektuplar, sohbetler ve hatıralarsa birinci elden kaynaklardır ve eserlerin farklı bir boyutta incelenmesine imkân tanımaktadır. Böylelikle dikkatler, eserden hareketle, eseri oluşturan sanatçıya çevrilmiştir.

Bir sanat yapıtını meydana getiren yegâne özne sanatçıdır. Bu nedenle esere yönelik incelemelerde, o eseri meydana getiren sanatçının yaşamöyküsünü, kişiliğini araştırmak uzun süredir kullanılan bir yöntem olarak karşımıza çıkar. Her şeyden önce bir cemiyet içersinde doğan sanatçının düşünsel hayatının gelişmesinde, geleceğe dair duygu ve düşüncelerinin belirlenmesinde denetleyici bir sosyal yapının ve toplumsal birliğin en küçük kurumu olan ailenin etkisi tartışılmazdır. Eserleri ve fikirleri ile

\footnotetext{
* Atatürk Üniversitesi, Yabancı Diller Yüksek Okulu, Türk Dili Okutmanı
} 
topluma yön veren insanların, ailelerinden aldıkları millî, dinî, ahlakî ve içtimaî terbiyeyi topluma yansıttıkları bir gerçektir.'

Sanatçının düşünce dünyasıyla birlikte, ruhsal özelliklerinin de eserlerine yansıdığı muhakkaktır. "Şiirin bir duygu meselesi olduğunu kavramış ve bunu eserleriyle göstermiş bir insan olarak Yahya Kemal'in de" (Kaplan, 2007: 223) çocuklukta içinde bulunduğu ortamın ve aile hayatının, eserlerinde ve kişiliğinin oluşumunda büyük etkileri olmuştur. Şair, Türk tarihinin en çalkantılı dönemlerinden birinde yaşamış ve ağır savaşlara, imparatorluğun çöküşüne, yeni Türkiye'nin kuruluşuna tanıklık etmiş, Osmanlılık görüşünün tasfiye edildiği redd-i miras günlerinde şiir ve söylemleriyle Osmanlı mirasına sahip çıkmıştır. Mazinin şanlı günlerine dönüş ve şiirin gözlerini maziye çeviriş belki de onun eserleriyle ilk kez bu kadar belirgin olmuştur.

Almış olduğu eğitim, devrin şartları, içinde bulunduğu sosyal çevre elbette bu görüşlerinin oluşmasında etkilidir. Ancak üzerinde çok durulmasa da Yahya Kemal'in gerek estetik, gerekse fikrî temayüllerinin gelişmesinde en önemli isimlerden biri annesi Nakiye Hanım'dır. İslâm tesettürünün en şedîd bir muhîtinde doğduğu, yaşadığı ve öldüğü için bir resmini bile bırakmadan kaybolan Nakiye Hanım, Leskofçalı Dilaver Bey ile İvranyalı Adile Hanım'ın üç kızının en büyüğüdür (Yahya Kemal, 1973: 5).

1877 yılında Osmanlı Rus Savaşı'nın neden olduğu olaylar neticesinde Sırbistan topraklarında oluşan kargaşa, Âdile Hanım ve Dilaver Bey'i topraklarından ayrılıp, Vranya'ya göç etmeye zorlar. Tam yaralar sarıldı derken Dilaver Bey'in ölümü, Âdile Hanım'ı, üç kızı ile birlikte yaşam mücadelesine sürükler. Kocasının ölümünden sonra Vranya'da Sırplarla komşuluk edemeyeceğini anlayan Âdile Hanım, toplumsal yapısı nedeniyle kendileri için uygun bir yer olan Üsküp'e taşınır. Kızlarını yuvadan uçurma zamanı geldiği hâlde, Nakiye Hanım'ı kimselere layık göremeyen Âdile Hanım, nihayetinde kızını Nişli ibrahim Naci Bey'e vermeyi uygun bulur. Bu genç servet sahibi değildir ancak Rumeliler arasında önemli bir yeri olan evlâd-ı fatihân'dan gelmektedir. Rumeli'nin ilk fatihlerinin soyundan gelen bu ailelerin birbirlerinden kız alıp vermeleri makbul görüldüğünden, Âdile Hanım, fakir ama soyu temiz bir bey olarak gördüğü ibrahim Naci Bey'i damatlığa kabul eder. Bu kabulde ibrahim Naci Bey'in içgüveysi olarak eve gelmeyi kabul etmesinin de tesiri vardır. Böylece evleri erkeksiz kalmayacaktır. Aynı zamanda da aileler akrabalık noktasında birleşmektedirler. İnce uzun boylu, siyah gür bıyıklı, kibar tavırlı bir genç olan ibrahim Naci Bey hakkında etraftan iyi şeyler duyulmasa da, Âdile Hanım her söze kulağını tıkar ve dillere destan bir düğünle kızını evlendirir (Uysal, 2006: 33-44).

1883 yılında evlendiklerinde Nakiye Hanım 19, ibrahim Naci Bey 21 yaşındadır. Oldukça hassas bir insan olan Nakiye Hanım'ın kocası ile ilgili şüpheleri vardır. İbrahim

'Edebî eser eleştirisinde sanatçı ve biyografi ilişkisi hakkında ayrıntılı bilgi için aşağıdaki kaynaklara bakılabilir: Berna Moran, Edebiyat Kuramları ve Eleştiri, iletişim Yayınları, ìstanbul 2007; R. Wellek, A. Warren, Yazın Kuramı, (Çev. Yurdanur Salman, Suat Karantay), Adam Yayınları, ìstanbul 2001. 
Naci Bey'in çapkın ve hercai oluşu, işrete ve alafrangalaşmaya meraklı yapısı nedeniyle, genç eşin duyduğu korku gerçek olacak ve huzursuzluklar kısa zamanda başlayacaktır.

Yahya Kemal, annesini şöyle anlatır: "hatırlayabildiğim kadar annem orta boylu idi. Kumraldı; semizliğe meyyâl bir bünyedeydi. Çok hisli ve asabiydi. Okumak ve yazmak bilmezdi. Çok kuvvetli mûtekıddi. Beş vakit namazını kılardı. Vekar ve haysiyet bahsinde müfrit bir derecede hassasdı. Rencîdeliklerini onulmaz yaralar gibi saklardı" (Yahya Kemal, 1973: 2).

Gerçekten de Nakiye Hanım kocasının yaptıkları karşısında uzunca zaman sessiz kalmış, alkol müptelası olan eşini evde tutmak için ona sofralar bile kurmuştur. Yahya Kemal'in "babam ailemizde arada bir görünürdü" dediği bu keyif ehli, okuyup yazma bilen, memleket meseleleri hakkında tartışmayı seven ibrahim Naci Bey ile okuyup yazması olmayan, ancak geleneklere sıkı sıkıya bağlı eşi arasında ortak bir nokta yoktur. Gerek hayata bakışı, gerekse iç güveysi olarak aileye damat oluşunun onda yarattığı eksiklik duygusu ve kendini ispat çabası, ibrahim Naci Bey'i boğar. Yaşadığı tekdüze aile babalığı rolünden sıkılır ve zevcesinin ısrarıyla evde içtiği içkisini artık dışarıdaki neşeli arkadaş ortamlarında içmeye, eve her gün biraz daha geç gelmeye başlar. Aile içinde ibrahim Naci Bey'e "yeter" sesleri arttıkça, o da babası Yunus Refet Bey'i görmek bahanesiyle Selanik'e gidip gelişlerini sıklaştırır. Oradaki canlı hayata özenen ibrahim Naci Bey, ailesini de yanına taşımak için teklifte bulunur. Ancak Üsküp'e manevî olarak bağlı bulunan Nakiye Hanım, bu teklifi şiddetle reddeder. O sırada patlak veren 1897 Türk-Yunan Savaşı, ibrahim Naci Bey'e aradığı fırsatı verir. Güvende olmadıkları gerekçesiyle ailesini göçe zorlar. Orada iyi bir iş bulacağından ve karısını mustarip olduğu veremden kurtaracağından emindir. Nakiye Hanım'ın ısrarla direnmesi sonucunda ibrahim Naci Bey niyetinin ciddiliğini anlatmak için, karısının çeyizlik eşyasını hamallar sırtında tellallar çarşına yollar ve bu eşyaları haraç mezat sattırır. $O$ devir için köklü ailelerce bir zül kabul edilen bu olay sonucunda Nakiye Hanım yataklara düşer. Yahya Kemal de hatıralarında bu konuyu, "annemin asıl ıztırabı yuvasının müebbeden dağıldığını hissetmesinden geliyordu. Zavallı ümmî kadın ne kadar doğruyu görüyormuş! Hakîkaten o zamandan sonra kendi öldü, biz evlatları küçük yaşta dağıldık, perîşan olduk, hâsılı o gün bu gün bir daha bir çatı altında birleşemedik" diyerek anlatır. Artık Nakiye Hanım'ın kocasına direnecek gücü kalmamıştır ve tam bir Müslüman muhiti olarak değerlendirdiği, etrafı camii, mezarlık ve ermiş türbeleriyle dolu olan Üsküp'ten, “Yahudi ve gâvurla karışı bir ağyar diyarı” Selanik'e gitmek üzere bir Nisan günü trenle ayrılırlar. Yahya Kemal'in deyimiyle, Üsküp'ü bütün kalbiyle seven annesi için bu ayrılış oldukça feci olmuştur. (Yahya Kemal, 1973: 5-7).

Selanik'te, kocasının sefalarından, oğullarının ilgisizliğinden bunalan ve hastalı̆gı tüm ciğerlerini saran bedbaht kadın bir an önce bu şehirden uzaklaşarak Üsküp'e dönmek ister. Ibrahim Naci Bey de Reşat ve Rukiye'yi yanına katarak Nakiye Hanım'ı memleketine gönderir. Yahya Kemal yeni başladığı okulu nedeniyle, babası da biraz daha eğlenmek hevesiyle Selanik'te kalırlar ve nihayet yaz sonunda Üsküp'e dönebilirler. Nakiye Hanım artık ölüm döşeğindedir. 1897 yılının Eylül ayında Üsküplüler'in Nakış Hanım dediği Nakiye Hanım ölür ve Yahya Kemal'in hayatı bu ölümle kökten değişir. 
Ayvazoğlu'nun dramatik bir karakter olarak işlediği Nakiye Hanım, birlikte oldukları kısacık süre içerisinde oğlunun kişiliğini nakış nakış işlemiş ve Yahya Kemal hayata annesinin gözüyle bakmaya başlamıştır (Ayvazoğlu, 2006: 83).

Cloud ve Townsend'in araştırmasında, karakter olarak kırılgan anne sınıfına giren Nakiye Hanım'ın ölümü, ileride Yahya Kemal'in ruhunda boşluk duygusunun ve hudutsuzluğun yerleşmesinde etkili olacaktır. Annenin erken yaşta kaybı veya çeşitli nedenlerle annesinden ayrı kalan erkek çocuklarının hayata karşı daha güvensiz, eğitim hayatında başarısız olduğu ispatlanmıştır. Annenin kaybı çocukta sık sık ve uzun süreli hastalıklar, bir yere, kişiye ve sorumluluğa bağlı kalamama ve çabuk sıkılma, empati yetersizliği gibi pek çok duygusal sorunu hazırlamaktadır (Cloud ve Townsend, 2006: 25-29). Yahya Kemal de annesine çok düşkün bir çocuk olarak, ömrü boyunca hastalıklar, yarım kalan eğitimler, güvensizlik gibi pek çok sorunla yüz yüze kalacak, hayatı her şeyden öte kendi ile mücadele ederek geçecektir. Ayrıca sanatı da annesinin tesirleriyle şekillenecektir.

Yeri gelince belirtileceği üzere, şairin şiirlerinin hemen hepsinde çocukluğunun ve annesinin tesirleri belirgindir. Ancak bu makalede şairin doğrudan annesini konu aldığı "Ezan-ı Muhammedî", "Nazar", "Hayal Şehir" ve "Uffuklar" şiirleri ekseninde Yahya Kemal'in din, tarih, ölüm ve folklor konularına bakışı konu edilecektir.

\section{Anne ve Din:}

Benim hem dinî hem millî terbiyem üzerinde daha şiddetle müessir olan annemdir. (Banarlı, 1960: 24) diyen Yahya Kemal, çocukluk dönemini manevî ve mistik yönü oldukça kuvvetli olan Üsküp'te yaşamıştır. Bu coğrafya şairin benliğine ilk ruhî serpintileri ekmiştir. Üsküp'e bağlı olarak şairin dine yaklaşımında etkili olan tek isim annesidir. Yahya Kemal'in nazarında ìslâmiyet anne ile özdeşleşmiş; şairin ezan seslerine, camilere, türbelere ve dinî ritüellere yönelişi annesinden kendisine kalan öğütler çerçevesinde şekillenmiştir. Hatta Yahya Kemal, dine en uzak olduğu zamanlarda bile ezân seslerinin kendisine verdiği huzuru, annesi ile geçirdiği zamanlara bağlar. Dini annesi ile özümseyen Yahya Kemal, "Ezân-ı Muhammedî" gazelini,

“Üsküp'de kabr-i mâdere olsun bu nev-gazel

Bir tuhfe-i bedî ü beyân-1 Muhammedî." (Yahya Kemal, 1962: 43-44)

diyerek, annesinin kabrine hediye eder ve annesinin kendisine verdiği ilk dinî terbiyeyi cevapsız bırakmaz.

Nakiye Hanım'ın ölümünün ardından şaire annesinden kalan ses, bir ezânın huzuruyla gelir. Onunla ezânı dinleyişlerini anımsar ve annesinin munis sesi, Yahya Kemal'in ruhunda ezân sesi ile bütünleşir. Nitekim bu sese duyduğu sevgi ona "Süleymaniye'de Bayram Sabahı"nı yazdıracaktır.

"Ezân-1 Muhammedî"de,

"Ervâh cümleten görür Allahü Ekber'i

Akseyleyince arşa lisân-1 Muhammedî” (Yahya Kemal, 1962: 43-44) 
diyerek, annesinin ruhuna ezân sesini ulaştırmak istemiş ve bu sesin göğü, nura gark ettiğini anlatmıştır.

Şairin "anne millet" imajını zihinlere yerleştirdiği "Ezânsız Semtler" ${ }^{2}$ yazısı da çocukluk dönemlerini bizlere hissettirmektedir. Yahya Kemal'in en mutlu günlerinin annesinin dizi dibinde Türk ve Müslüman Üsküp'te yaşadığı günler olduğu aşikârdır.

Yahya Kemal'in ruhunda anne, bir ses olarak tecessüm etmektedir. Öyle ki hayalinde çizdiği silueti dışında annesinin sesi daha canlı bir hatıra olarak şairin kulaklarında kalmıştır. Nakiye Hanım'ın oğluna söylediği ilahiler, Yahya Kemal'de "hem hazin hem ruhanî duygular uyandırır" (Banarlı 1960: 24) ve küçüklükte sağlam bir inanç sevgisi almasını sağlar.

Yine Nakiye Hanım'ın, Yazıcızade Mehmet Efendi'nin Muhammediye'sinden okuduğu mısralar, Yahya Kemal'in gözleri önünde farklı dünyalar açar ve şair, hatıralarında o günlerle ilgili olarak "bizim öz maceramız, evimizin, mahallemizin, Üsküb'ün ve müphem sûrette bütün milletimizin dünya ve ahiret macerası gibi gelirdi. Daha o yaşta Yazıcızade Mehmet Efendi'nin Türklükle İslâmlı̆̆ı yoğuran, millî, ìslâmî harsını benliğimde hissetmeğe başlamıştım" der (Banarlı 1960: 25).

Nakiye Hanım'ın namazını düzenli olarak kıldığını, akşamüstleri ölülerine Yasin okuduğunu, Yahya Kemal'e ahiret hayatına dair bilgiler verdiğini ve dine düşkünlügünü şairin hatıralarından öğreniyoruz. Yine şairin bayram namazlarına annesinin telkinleri ile gittiğini de hatıralarından tespit etmekteyiz. Şiirlerinde sıklıkla yer eden bayram sabahı imgesinin, annesinden kendisine kalan bayram hatıraları ile yoğrulduğunu söyleyebiliriz.

Yahya Kemal, annesini kaybettikten sonra "dine dair ilk sofuluğa" geçiş yaptı̆̆ını söylemektedir. Bunu "ilk sofuluğum, on üç yaşında annemin ölümüyle başladı. İsa Bey Câmii'nde annemin rûhuna her akşam Yâsin okumağa başladım. Müslümanlık âlemine o kapıdan girdim diyebilirim" sözleriyle ifade eder (Uysal 2006: 54). Müslüman Türk çocuklarının dinî ve millî terbiyesinde ezân seslerinin oldukça önemli olduğuna sürekli olarak değinen Yahya Kemal, Paris'te bulunduğu zamanlarda kulağına zaman zaman ezân seslerinin geldiğini ve bu seslerin ona annesini ve Üsküp'ü hatırlatarak nostaljik bir sızı verdiğini de dile getirmiştir.

Ahmet Hamdi Tanpınar, Yahya Kemal'in din meselesinde hiçbir teklifi veya inkârı olmadığını söyler (Tanpınar 1995: 50). Yine Tanpınar'a göre Yahya Kemal, dini, Türk halkının "hem yapıcısı hem en sahih aynası" addeder. Şair, içtimai bir yapı olarak düşündüğü dini, katı kurallardan sıyrılmış ve medeniyetin bir unsuru, katkılarla kurulan bir temeli olarak değerlendirmiştir. Yahya Kemal'in din konusundaki bu görüşleri üzerine tartışmalar ve söylenenler çoktur. ${ }^{3}$ Ancak annesinden aldığı dinî terbiyenin

\footnotetext{
${ }^{2}$ Bu yazı için bakını: Yahya Kemal, Aziz Istanbul, İstanbul Fetih Cemiyeti Yayınları, ìstanbul 1964.

${ }^{3}$ Bu konudaki tartışmalar için aşağıdaki makalelere bakılabilir: Kaya Bilgegil: "Yahya Kemal'in Şiirlerinde Din”, Kaya Bilgegil'in Makaleleri, (Haz. Zöhre Bilgegil), Akçă̆ Yayınları, Ankara 1997, s. 547-575; Orhan Okay: Deizm Polemiği ve Yahya Kemal'de Din Duygusu", Yahya Kemal
} 
Yahya Kemal'in dine duygusal bakışında ve kalıplar dışı değerlendirişinde etkisi olduğu muhakkaktır.

Ezan-ı Muhammedî gazelinde Yahya Kemal dinde itikadın ve gazanın önemine değinir ancak gazelin sonunda din, annesinin kendisine hatıra bıraktığı biçimiyle yani estetik yönüyle görünür.

\section{Anne ve Tarih:}

Yahya Kemal, Türklüğü yakından duyumsayan ve manevî havası oldukça yüksek olan Üsküp şehrinde doğmuştur. Üsküp'ün Balkan coğrafyasında olması ve Balkanlar'ın hareketli yapısı, Yahya Kemal'de kayıp duygusu kadar, tarihe ve milliyetçiliğe dair duyguların da hızla perçinlenmesini sağlayacaktır.

Bilindiği gibi şairimiz hem anne hem de baba tarafından, Rumeli'nin fethinde bulunan ilk isimlerden Şehsuvar Bey'in soyundan gelmiştir. Soyadını Beyatlı olarak almasından da anlaşıldığı üzere, şair bu "akıncı ceddine" büyük bir hayranlık duymaktadır. Kendisinde akıncılık duygusunu perçinleyen soyunun duygu dünyasına kattığı nüveleri, Nakiye Hanım daha da kuvvetlendirecek ve Yahya Kemal'in tarih sevgisinin dayandığı Üsküp, ailesi ve Paris ayakları Kayıp Şehir ile kendini açı̆̆a çıkaracaktır. Şairin:

"Üsküp ki Yıldırım Beyazıd Han diyârıdır,

Evlâd-ı Fâtihân'a onun yâdigârıdır” (Yahya Kemal 1967: 77-78)

diyerek başladığı “Kayıp Şehir”, Balkanlar'ın acı kaderine tanıklık eden Yahya Kemal'in doğduğu topraklarla ilişkisini ve şairin romantik tarih anlayışını özetleyen bir şiirdir denilebilir.

Nakiye Hanım, Yahya Kemal'in vatan toprağını kutsal bilmesinde, milliyetine bağlanmasında hayli etkili olmuştur. Onun nazarında Müslümanlık ve Türklük birbirinden ayrılmaz, oğluna da bu yönde öğütler verir. Yahya Kemal annesinin kendisine iki kişiyi çok sevmesi gerektiğini öğütlediğini söyler. Bunlar birincisi Hazreti Peygamber, diğeri de Sultan Murat'tır. O devirde, Rumeli'yi Türkleştiren ve Müslümanlaştırarak bir birlik oluşturan 1. Murat ve ll. Murat'ın birleşiminden oluşan bir kült sembol halinde kullanılan Sultan Murat ifadesi, annesinin Rumeliliğe ve vatan sevgisine olan bakışını anlatmaktadır. (Banarlı 1960: 25-26).

Arkadaşlarına “inşallah oğlum şehit olur" diyerek ağlayan (Banarlı 1960: 26) Nakiye Hanım'ın ölümünden sonra zorunlu olarak başlayan gurbet, Yahya Kemal'in görüşlerini ve düşüncelerini daha da belirginleştirir. Annesi ile birlikte geçirdiği zamanların hatırasıyla ruhunu avutmak isteyen şair, yaz aylarını anneannesi Adile

Enstitüsü Mecmuası, Cilt: IV, 2001, s. 64-74; Sait Bașer; Yahya Kemal'de Türk Müslümanlı̆̆ı, Seyran Yayınları, İstanbul 1998; Süleyman Ceran, "Yahya Kemal ve Türk Müslümanlı̆ı", Hece Dergisi, Yahya Kemal Beyatlı Özel Sayısı, Ocak 2009, s. 132-136.Süleyman Hayri Bolay; "Yahya Kemal ve Din" Ölümünün Yirmi Beşinci Yılında Yahya Kemal Beyatl, TKAEY, Ankara 1983, s. 195-218. 
Hanım'ın Niş, Vranya ve Rakofça çevresindeki çiftliklerinde geçirir. Buradaki duygusal hava ile akıncılı̆̆ı, zaferleri daha sık düşlemeye ve o "hür havaları" teneffüs etmeye başlar. "Açık Deniz" ve "Akıncı", o esintilerin yıllar sonra dilde somutlaşan ifadesi olur. Babası, eşinin ölümü üzerinden hemen bir yıl geçmişken Selânik Mevlevî Şeyhi Eşref Bey'in yeğeni Mihrimah Hanım ile dünya evine girer ve yeni hanımının isteğine uyarak başka eve çıkar. Nakiye Hanım'ın cenazesinin çıktı̆̆ı, Yahya Kemal'in büyüdüğü ve hatıralarla dolu olan evleri ise bir askere kiralanır. Ailelerinden sonra artık evleri de dağılmıştır. Şairimiz gördüğü bu vefasızlıklara dayanamaz ve sık sık evi terk etmeye başlar. Kışları akrabaları Yaşar Bey'in Butel'deki çiftliğine gider; yazları ise anneannesinin yanında kalan kız kardeşini görmek bahanesiyle Üsküp'te geçirir. Ancak evlerinde bir yabancının oturduğunu görmesi, yüreğini yaralamaktadır: "merhûme annemin hatırâları, onun o eve ettiği ihtimam, onun oradaki orta salonda ölümü, ilâ-âhir birçok şeyler zihnimi sarıyor, oradan boynu bükük bir insan gibi geçiyordum" (Uysal 2006: 78) diyerek anlattığı bu hüzünlü gurbet hayatı, Yahya Kemal'e bambaşka bir esinti getirecektir.

İstanbul'a gidip okula devam etmeye çalışan Yahya Kemal, uzun süreli bir hastalığa tutulur ve tekrar Butel çiftliğine gelir. Artık babası ve üvey annesi de annesinin evinde oturmaktadırlar. Annesinin evinde başka bir kadın görmeye tahammülü olmayan şairin hayatı oradan oraya savrulurken, Yaşar Bey bu mazlum delikanlıyı Galatasaray Lisesi'ne aldırmak için çabalar. Fransızca bilmediği için çeşitli bahaneler gösterilerek buraya alınmayan şair için, devrin ruhundan etkilenerek hayran olduğu Paris'e gitmek fırsatı böylece doğar. "Osmanlıcılık ve Müslümanlığı terk eden ruhla Paris'e” giden, ancak "milliyetinin kıymetini Paris'te" duyacak olan Yahya Kemal için yeni bir sayfa açılır. (Uysal 2006: 96).

Paris'te aldığı dersler onun vatan anlayışının ve fikirlerinin gelişmesinde etkilidir. Albert Sorel'in düşünceleriyle şekillendirdiği vatan algısı, anne millet/ anne toprak anlayışı ile birleşir ve yaşanılan toprağın vatan olarak idraki gündeme gelir. Yahya Kemal için Anadolu toprağı vatandır ve o toprakta yaşayanlar vatanın evlatlarıdır. Yahya Kemal milliyetçiliğinin başlangıcında geniş ve ütopik bir düzen vardır. Zamanla görüşünü oluşturan şair, Fransız tarihçisi Sorel'in düşüncelerini Türk milleti için uygulamaya çalışır. Durkhaim'in ırka dayalı milliyetçilik fikrinden etkilenir ve zihninde "toprak = millet" kavramını örtüştürür. ${ }^{4}$

Tüm bu etkiler sonucunda Yahya Kemal'in tarihe bakışı romantik bir estetiğe yaslanır ve ona göre tarihte devamlılık esastır. Bu nedenle de tarihi bir noktada kesintiye uğratmaktan yana değildir. Diğer taraftan "Tarih Musahabeleri”nde ${ }^{5}$, tarihin topyekûn

4 18. yüzyılda Avrupa'nın Türkiye'ye bakışı netleşecek ve amaçları Türkleri geldikleri yere göndermek olacaktır. Bu amacın sonunda Islahat Fermanı ile azınlık haklarının korunması maddesi Osmanlı hayatına girmiş, I. Dünya Savaşı sonunda da bu maddeye dayanılarak Osmanlı toprakları işgal edilmiştir. Sınırların daralması, devrin aydınlarını milletin ayağını basacağı bir zemin bulma telaşına sürükler. Remzi Oğuz Arık tarafindan adı koyulan Anadoluculuk fikrinin babası olarak Yahya Kemal'i görürüz.

${ }^{5}$ Bakınız: Yahya Kemal, Tarih Musahabeleri, İstanbul Fetih Cemiyeti Yayınları, İstanbul 1991. 
sevilecek bir şey olmadığını söyler. Annesizliğin insan ruhunda yarattığı etkileşim olarak da değerlendirilebilen bu görüşte Yahya Kemal, kendisini mutlu edecek şeyleri esas alarak zafer ve fetih dönemlerine, yani kolektif şuura yönelir. Coğrafya ve tarihin birliğine dayanan tarih anlayışında Yahya Kemal'in önemli bir düşüncesi de toprağın vatan olması için, orada ilk doğan ve ölene ihtiyaç olduğu görüşüdür. Ona göre mezarlıklar tarihle eşittir; mezar taşları ise dondurulmuş bir tarihtir ve aidiyeti gösterir. "Kayıp Şehir" şairin bu görüşünü destekler:

"Ben girmeden hayâtı şafaklandıran çağa,

Bir sonbaharda annemi gömdük o toprağa.

isâ Bey'in fetihte açılmış mezarlı̆ğ

Hulyâma ahret gibi nakşetti varlı̆̆

Vaktiyle öz vatanda bizimken, bugün niçin

Üsküp bizim değil? Bunu duydum, için için” (Yahya Kemal 1967: 77-78)

Yine mimarî de şairin tarih anlayışında önemli bir yer tutar. Parlak zaferlerin muzaffer unsurları olan ve dondurulmuş bir tarihi veren mimarîler, kişiye şuur kazandırır. Mimarî yapının tarih anlayışına etkisi "Kaybolan Şehir"de şu ifadeyle gelir:

"Firûze kubbelerle bizim şehrimizdi o;

Yalnız bizimdi, çehre ve rûhiyle biz'di o" (Yahya Kemal 1967: 77-78)

Yahya Kemal'in çocukluğunu geçirdiği ve annesi ile özdeşleştirdiği Üsküp onun tarih anlayışında önemli bir yere sahiptir. Ömrü boyunca Üsküp dokusunu veren yerleri sevecek olan şairimiz, "Koca Mustâpaşa" ve "Atik Valde'den İnen Sokakta" şiirlerinde de, Üsküp'ü bir şekilde arayacaktır (Ünver 2000: 125-149). Şairin Üsküp'e olan bu ilgisi, annesi ile orada paylaştıklarına bağlıdır. Üsküp'ü kaybetmek, şairi yıkan bir olay olur. Kaybedilen toprak psikolojisi, onda bir trajedi olarak görülür. ${ }^{6}$ Anne onun için tarih ve kaybedilen toprak demektir. "Kaybolan Şehir" bu görüşün cisimleştiği ve anne ile Üsküp'ün birleştiği bir şiirdir:

"Kalbimde bir hayâli kalıp kaybolan şehir!

Ayrılmanın bıraktığı hicran derindedir!

Çok sürse ayrılık, aradan geçse çok sene,

Biz sende olmasak bile, sen bizdesin gene" (Yahya Kemal 1967: 77-78)

Görüldüğü gibi Yahya Kemal, annesinin ölümü ile Üsküp şehrinin tarihini birleştirmiş ve annenin kaybı bir şehrin, kültürün ve medeniyetin kaybını simgelemiştir.

\section{Anne ve Ölüm:}

Yahya Kemal'in şiirinde hasret ve kayıplar, ölüm teması sıklıkla yer eder. Annesini on üç yaşında iken kaybeden şair, ölümle ilgili düşünceleri erken yaşta, acı deneyimlerle kazanmıştır. Ölüm Yahya Kemal şiirlerine ışık, aydınlık, ufuk ve özlem ile girer. Çocuk Yahya Kemal, annesinin ölümünü idrak eder ve Yahya Kemal devamlı anneye döner.

${ }^{6}$ Yahya Kemal'in tarih görüşü için bakınız: Yaşar Şenler, Kültür ve Edebiyata Dair Görüşleriyle Yahya Kemal, Ötüken Yayınları, İstanbul 1997. 
Abdülhak Hamit ile şiire giren metafizik düşünce, Yahya Kemal ile boyut değiştirir. Yahya Kemal dindardır ve ölümden korkmaz, ölülerle birlikte yaşama duygusu vardır. Ölüm onun gözünde açık bir denizde canana yelken açmakla eşdeğerdir. Yahya Kemal için ölüm seyyal bir sahadır. "Ufuklar"da şöyle der:

"Rûh ufuksuz yaşamaz

Dağlar ufkunda mehâbet,

Ova ufkunda huzûr,

Deniz ufkunda tesellî duyulur.

Yalnız onlarda bulur rûh ezelî lezzetini" (Yahya Kemal 1967: 95)

Nakiye Hanım kronik rahatsızlı̆̆ı bulunan bir annedir. Bu tür annelerin çocuklarına aşırı düşkün oldukları ve bu düşkünlüğün çocuğu anneye bağımlı kıldığı belirlenmiştir. (Tortumluoğlu 1999: 35). Yine uzmanlar, anne çocuk ilişkisinin hastalık, ölüm veya ayrılık nedeniyle bir biçimde sekteye uğramasının, bireyin ruh dünyasında onulmaz yaralar açacağını söylemektedir. Leona Siebenschön'ün Tebeşir Dairesi'nde belirttiği kadarıyla annesini erken yaşlarda kaybeden çocuklarda annesizliği kabullenememe, ölmek isteme, içe kapanma ve yalnızlık duygusu belirgin olarak görülmektedir (Fritsch 1985: 87-93).

Yahya Kemal, annesinin ölümünün ardından şiddetli bir içe kapanma ve ölmek isteği ile dolmuştur. Selanik dönüşü annesini ölüm döşeğinde bulan şair, o günkü duygularını şöyle anlatır: "Kendisini, Karaağçlar altındaki evimizin büyük salonunda, yatakta, kendine bakanlar ortasında, ölüm yatağında bulduk. Nitekim ölüm de gecikmedi... Evimizin üzerinde bir felâket dolaştığını ayan beyan görüyordum. O gece annemin hasta yattığı salonun yanında bir odada yatıp uyumayı istedim. Anneme bakan kadınlar râzı oldular. Belki de annemin de arzusu buydu. Gece uzun müddet uyuyamadım. Yorganımın altında ağladım. Uyuyunca da korkulu rü'yâlara daldım. Bu rü'ya içinde hayatımda en fevkalâde bir hadise idrâk ettim: Rü'yamda annemin son nefesini verdiğini ve muhibbesi Naîme Hanım'ın kucağında çenesinin bağlandığını görüyordum. Bu rü'yanın korkusuyla uyandım. Yataktan fırladım. Odanın kapısını açtım. Hakîkaten annemi rü'yada gördüğüm vaziyetle Nâime Hanım'ın kucağında, çenesi bağlanırken gördüm. Rü'yada gördüğüm vaziyetle bu hakîkî hâdise birbirinin aynı idi. Bir manzara, aksettiği bir aynada nasıl görünürse rü'yamla bu hakîkî manzara da öyle idiler.

Müthiş bir çı̆̆lıkla annemin yatağına atılmak istedim. Oradakiler beni susturmağa çalışarak, uzaklaştırdılar. Tâ karşıda büyük annemin evine kadar götürdüler. Aradan yarım saat geçti. Büyük annem, teyzelerim, üç âilenin çocukları, felaketimize şitap eden âile dostları kadınlardan ağlaşan, sızlaşan bir kalabalık ortasında kaldık. Annem ölmüştü. Çıldırmış bir haldeydim. O anda ölmek, intihar etmek istiyordum. Bu müthiş yokluğa, bu derin acıya tahammül edemiyordum. Bir deliyi tutar gibi, sımsıkı tutuyorlardı; yüzümü, gözümü yıkıyorlardı. Heyhat ki ıztırâbım durmuyordu. Kocakarılar, ağlarsam annemin rûhu çok muztarip olacağını halbuki annemin istirâhat ettiğini, cennette hepimizin birbirimize kavuşarak, mes'ûdâne bir hayat geçireceğimizi, artık orada hiçbir zaman ölmiyeceğimizi, annemin bizi yakında cennette beklediğini 
söylüyorlardı. Bu tesellîden biraz avunuyordum; lâkin birkaç dakîka sonra kalbimin şifâ bulmaz üzüntüsü tekrar bir alev gibi parlıyordu. Annem gibi ölmek, hemen ona kavuşmak istiyordum. İntihar vâsıtalarının ne olduğunu düşünüyordum. lztırâbım orada toplanan herkesi sarmıştı. Hepsi de beni görerek daha fazla ağlaşıyordu. Öğleye doğru Alaca ve Sultan Murad câmîlerinin minârelerinden annemin rûhuna verilen su salâları işitildi. Beni büyük annemin evinden tekrar bizim eve geçirdiler. Bahçenin ortasında bir çadır kurulmuştu. Annem gaslolunacaktı. Yüzlerce kadın mendilleri yüzlerinde ağlaşıyorlardı. Nihâyet gasil bitti. Beni ve kardeşimi annemin yüzünü son bir defâ görmek üzere çadırın altına götürdüler. Annemin nâşı teneşir üzerinde beyaz bir kefenle örtülüydü. Yüzünü açtılar. Kendisini ruhsuz, gözleri açık ve gülümser bir hâlde gördüm; saçları etinden ayrılmış gibiydi. Târîf edemiyeceğim bir acı ile yüzüne bakmıyordum. Kendisi ile aramda ne kadar mesâfe olduğunu ölçemiyordum; yüzünü müebbeden hayâlime nakşetmek için, kalbimin bütün kuvvetiyle bakıyordum" (Yahya Kemal 1973: 9).

Annesinin ölümünün kendisinde yarattığı acıyı, gasil sırasında gördüğü manzarayı ve İsa Bey mezarlı̆̆ını hiç unutmayacak olan Yahya Kemal, "Ufuklar"da bu hatırasını şu şekilde şiirleştirecektir:

“Annemin na'şını gördümdü;

Bakıyorken bana sâbit ve donuk gözlerle.

Acıdan çıldıracaktım.

Aradan elli dokuz yıl geçti.

Ah o sâbit bakış el'an yaradır kalbimde.

O yaşarken o semâvî o gülümser gözler

Ne kadar engin ufuklardı bana;

Teneşir tahtası üstünde o gün,

Bakmaz olmuştular artık bu bizim dünyâya" (Yahya Kemal 1967: 95)

\section{Anne ve Folklor:}

Babasının adını Ahmet Âgâh koyduğu7 Yahya Kemal, 2 Aralık 1884 yılında, Üsküp İshakiye Mahallesi'ndeki “taş döşeli geniş avlusunda mermer pınarlarından gece

\footnotetext{
${ }^{7}$ Şair, babasına olan kızgınlı̆̆ı dolayısıyla adını önce Âgâh Kemal, daha sonra da Yahya Kemal olarak değiştirecektir. Annesine yürekten bağlı olan Yahya Kemal hayatının en aziz varlığını elinden alan babasını asla affetmeyecektir. Bu konuda Yahya Kemal'in mektuplarına başvurulduğunda çok uzak bir tanıdıkla konuşurcasına yavan ve uzak bir sohbet havası göze çarpmaktadır. Özellikle gitmek istediği edebiyat fakültesi ile ilgili olarak babasına verdiği bilgileri okurken bir baba oğul ilişkisi dışında mecburî bir öğrenci-hami ilişkisi göze çarpmaktadır. "Bütün hayât-ı tahsîlimi size medyûn olduğumdan bu vâdîde yalnız harekete zerre kadar hakkım yoktur. Siz neyi münâsip görürseniz o olur.” Alıntı için bkz. Yahya Kemal, Mektuplar Makaleler, Fetih Cemiyeti Yayınları, İstanbul 1990, s. 76-77.
} 
gündüz gürül gürül sular akan, büyük meyve, sebze bahçeleri bulunan; haremi altı, selâmlı̆̆ı da üç odalı" anneanne konağında (Uysal 2006, 49) doğmuştur. Bu büyük ve geniş konakta ailesinin yardımcılarından halk kültürüne dair oldukça malzeme edinmiştir. 'Nanamı tanımasaydım, Ernest Renan'ın naklettiği Hazret-i îsâ'yı ve Balzac'in tavsîr ettiği Baba Gorio'yu iyi anlayamazdım” (Yahya Kemal 1973: 12) dediği annesinin dadısı Fatma Hanım, Yahya Kemal için insanlığın ve sevginin katıksız halidir. Nana ile evli olan Ali Zaîm ise şairimize göre Rumelilik demektir. Ali Zaîm iyi işlenmiş mavi çakşırı, mavi cepkeni, geniş lâhuri kuşağı, boynuna astığı gümüş kösteği ve pos bıyıklı matruş yüzüyle katıksız bir Rumelilidir (Ayvazoğlu 2006: 78). Deli Ahmet Ağa, Yahya Kemal'in sütannesi Halime'nin eşidir ve "deli lakabını bir yeniçeri neferi gibi taşır" (Yahya Kemal, 1973: 13). Vardar'daki yüzme eğlencelerinin birinde neredeyse boğulacak olan Yahya Kemal'i kurtaran ve şairin hayatımın bakiyesini borçluyum dediği Deli Ahmet, gönül derdi açığa çıkınca evlerinden ayrılacak ve bir daha görünmeyecektir. Onun heybetli yapısı, deli dolu ve mertçe tavırları Yahya Kemal'i etkileyecek ve onun için "benim gözümle gördüğüm son yeniçeri idi" diyecektir. (Yahya Kemal 1973: 16) Niş muhacirlerinden Hüseyin adlı uşakları ise Yahya Kemal'in Son Osmanlıları'ndandır. Geceleri Yahya Kemal'e Battal Gâzi Destanı'nı okur. Kahramanlık hikâyeleri ve türküleri söyler. Üsküp'ü hafızasına anlattıklarıyla işler. Bu uşağın tavırları Yahya Kemal'i çok etkiler ve onun gibi külhanbeyliğe heves eder.

Daha önce de anıldığı gibi halk adamı tiplerine oldukça yakın olan bu yardımcılarından ilk nüveleri alan şairimiz folklora dair görüşlerinde, geçmişinden ve Üsküp'ün havasından etkilenir. Evsizlik ve mekânsızlık psikolojisi de Yahya Kemal'de tetikleyici bir unsurdur ve halk kültürüne yönelişini hızlandırır.

Balkan coğrafyasının savaşlarla dolu olan kaderi ve Yahya Kemal'in tanıklıkları da onun halk kültürünü Neo-Klasik kültür ile birleştirmesiyle sonuçlanır ve şiirinde bu yapının damıtıldığını görürüz. Örneğin 1897 Türk Yunan harbinde, Gazi Ethem Paşa orduları Atina'ya giderken, gönüllü Türk askerleri:

"Eğil dağlar eğil, üstünden aşam

Yeni tâlim çıkmış, varam, alışam."

Türküsünü söyleyerek orduya katılmışlardır. Bu durum Yahya Kemal'i derinden etkilemiş ve yıllar sonra ístiklâl Harbi Yazıları'na Eğil Dağlar adını vermiştir. Balkanlar'ı kaybetmek onun ruhunda derin acılar bırakmıştır.

Ve Nakiye Hanım... Yahya Kemal'in annesi ümmî bir kadındır. Onunla ettiği sohbetlerde Yahya Kemal, halk kültürüne dair çok şey bulur. Nazar'da annemin ölümü vardır (Ayvazoğlu, 2006: 102) diyen ve Leylâ'nın şeametli ölümü ile annesinin ölümü arasında bağ kurduğunu söyleyen şairin, bu şiirinde kimsesiz ve yalnız bir biçimde hayata veda eden annesine, folklorik bir yöneliş ile yaklaştı̆̆ını görürüz.

“...

Aranırken ayın ölgün sesini,

Soğuk ay öptü beyaz ensesini.

Sardı her uzvunu bir ince sızı; 
Bu öpüş gül gibi soldurdu kızı.

Soldu, günden güne sessiz, soldu!

Dediler hep: "Kıza bir hâl oldu!"

Evi rüzgâr gibi bir sır gezdi,

Herkes endîşeli bir şey sezdi.

Bir sabah söyledi son sözlerini,

Yumdu dünyâya elâ gözlerini;

Koptu evden acı bir vâveylâ,

Odalar inledi: "Leylâ! Leylâ!"

Geldi köy kızları, el bağladılar...

Diz çöküp ağladılar, ağladılar!

Nice günler bu şeâmetli ölüm,

Oldu çok kimseye bir gizli düğüm;

Nice günler bakarak dalgalara,

Dediler: "Uğradı Leylâ nazara!” (Yahya Kemal, 1967: 149- 150).

"Kendi annesinden rencîde, hemşirelerinden müteneffir, kocasından me'yus olan zavallı" Nakiye Hanım, "dünyâda yegâne tesellîsi olarak" oğluna tutunur (Yahya Kemal, 1973: 7). Bu ruh yakınlığında Yahya Kemal için de annesinin ölümü bir milat olarak değerlendirilebilir. Bir oidipal karmaşa olarak açıklanamayacak olan bu yakınlık, tamamen bir çocuğun annesini kaybetmesi sonucu değişen yazgısının sonucudur. Annesinin zamansız ve erken ölümünden babasını sorumlu tutan ve devamında babasının yeni hayatında kendisine bir yer bulamayan Yahya Kemal, hiçbir yere sığamamış ve çareyi gurbette bulmuştur. Evinden uzak kalışın ruhundaki tesirleri de hayata olan güvensizliğini artırmıştır. Şairin annesi ile geçirdiği yıllardan kendisine kalan nüveler, Nakiye Hanım'ın ölümü ile bir kutsiyet kazanmış ve Yahya Kemal gerek savruluşlarında gerekse hayata karşı takındığı tavırda o ilk intibalarıyla hareket etmiş ve adeta şiirimize "büyümeyen çocuk ruhu"nu bırakmıştır.

Sonuç olarak Nakiye Hanım'ın ölümünün, şair üzerinde farklı tesirler bıraktığını söyleyebiliriz. Ruhî tesirler bir travma etkisindedir. Yahya Kemal'in eğitiminin, tekrarlayan hastalıkları ve yaşadığı özlemler nedeniyle yarım kalması, hayatı boyunca hiç evlenememesi, sanatçı kaprisi olarak değerlendirilen geçimsizlikleri ve şairin içine kapanık yapısı gibi pek çok sorun annesinin ölümüyle ilişkilendirilebilir. Sosyal tesirler ise daha farklı bir boyutta gelişmiştir. Yahya Kemal'in fikir dünyasını şekillendiren ve onun hayata bakışını belirleyen pek çok başlıkta; sahip olduğu şiir görüşü, medeniyet anlayışı, hayata bakışı, duygu ve düşünce dünyasında Nakiye Hanım'ın etkileri kendisini belli etmektedir.

\section{KAYNAKÇA}

AYVAZOĞLU, Beşir, (2006), Bozgunda Fetih Rüyası, Kapı Yayınları, İstanbul.

BANARLı, Nihat Sami, (1960), Yahya Kemal'in Hatıraları, İstanbul Fetih Cemiyeti Yayınları, istanbul.

BAŞER, Sait, (1998), Yahya Kemal'de Türk Müslümanlığı, Seyran Yayınları, İstanbul. 
BilGGEGil, Kaya, (1997), "Yahya Kemal'in Şiirlerinde Din”, (Haz. Zöhre Bilgegil), Akçağ Yayınları, Ankara.

BOLAY, Süleyman Hayri, (1983), "Yahya Kemal ve Din” Ölümünün Yirmi Beşinci Yılında Yahya Kemal Beyatl, TKAEY, Ankara.

CERAN, Süleyman, (2009), "Yahya Kemal ve Türk Müslümanlı̆̆ı”, Hece Dergisi, Yahya Kemal Beyatlı Özel Sayısı.

CLOUD, Hanry, (2006), John Townsend, Anne Faktörü, (Çev. Emel Aksoy) Sistem Yayınları, İstanbul.

FRiTSCH, İna, (1985), Anne Baba Boşanıyor, (Çev. Leman Çalışkan), Afa Yayınları, istanbul.

KAPLAN, Mehmet, (2007), Şiir Tahlilleri ı, Dergâh Yayınları, i̇stanbul.

MORAN, Berna, (2007), Edebiyat Kuramları ve Eleştiri, illetişim Yayınları, İstanbul.

OKAY, Orhan, (2001), “Deizm Polemiği ve Yahya Kemal'de Din Duygusu”, Yahya Kemal Enstitüsü Mecmuası, Cilt: IV.

ŞENLER, Yaşar, (1997), Kültür Ve Edebiyata Dair Görüşleriyle Yahya Kemal, Ötüken Yayınları, İstanbul.

TANPINAR, Ahmet Hamdi, (1995), Yahya Kemal, Dergâh Yayınları, İstanbul.

TORTUMLUOĞLU, Gülbu, (1999), Annelerin Aile Kavramını Algılaması Ve Bunun Çocuk Yetiştirme Tutumuna Etkisi, Yayımlanmamış Yüksek Lisans Tezi, Erzurum.

UYSAL, Sermet Sami (2006), Yahya Kemal Beyatlı, Bilge Yayınları, İstanbul.

ÜNVER, A. Süheyl, (2000), Yahya Kemal'in Dünyası, Şehir Yayınları, İstanbul.

WELlEK, R., A. Warren, (200ı), Yazın Kuramı, (Çev. Yurdanur Salman, Suat Karantay), Adam Yayınları, İstanbul.

Yahya Kemal, (1964), Aziz ìstanbul, ìstanbul Fetih Cemiyeti Yayınları, ìstanbul. , (1973), Çocukluğum, Gençliğim, Siyâsî Ve Edebî Hatıralarım, İstanbul Fetih Cemiyeti Yayınları, ìstanbul.

, (1962), Eski Şiirin Rüzgârıyle, İstanbul Fetih Cemiyeti Yayınları, İstanbul.

, (1967), Kendi Gök Kubbemiz, İstanbul Fetih Cemiyeti Yayınları, İstanbul.

, (1991), Tarih Musahabeleri, İstanbul Fetih Cemiyeti Yayınları, İstanbul.

, (1990), Mektuplar Makaleler, İstanbul Fetih Cemiyeti Yayınları, İstanbul. 